\title{
Critique of the Cruelty of the Iraq War: The Symbolism in Kevin Power's The Yellow Birds
}

\author{
Zainalabdeen A.Al Shnain AL-Janabi, Aihua Chen \\ Huazhong University of Science and Technology, Wuhan, China
}

\begin{abstract}
The Yellow Birds novel is written by the American writer Kevin Powers who is an Iraq War veteran. In this novel, he presented his memories and terrible experiment during his service. The novel has been acclaimed as one of the best contemporary novels on war, not only for its literary value but also for its boldness to reveal America's role in spreading destruction in the world since its inception. One of the novel's striking features is that the American soldier is not depicted as a hero who came to save Iraqi people from a tyrant and to bring democracy on a dish of gold, but as a human being divided between death and survival. Powers uses many different symbols to express his convictions and ideas. Symbolism is a very important instrument in the formation of the story. He used symbols to accentuate the meaning of a story and explain certain actions of a character, as a major tool to improve the personality of his characters, to represent different themes and set up events. Therefore, the main concern of this paper is to identify the major symbols that Powers has used in this novel and elucidate on their significance.
\end{abstract}

Keyword: symbolism, Kevin Powers, The Yellow Birds

\section{Introduction}

The word "symbol" is primarily derived from the Greek verb "Symballein", which means "to put together" and the related noun "Symbolon” which means "mark", "take”, or "sign” (Edgar \& Jacobs, 1989). Whereas, the term "symbol" refers to an object, person, place, or action that has a meaning in itself and also stands for something larger than itself, such as a quality, an attitude, a belief, or a value (Perrine \& Arp, 1974). A symbol is something that typifies, states for, or proposes a notion, belief, action, or entity (Feidelson Jr, 1953). Symbolism is the practice or art of using an object or a word to represent an abstract idea. An action, person, place, word, or object can have a symbolic meaning. When the author wants to propose a particular mood or emotion, he can also use symbolism to hint at it, rather than just blatantly saying it (May, 1960). Symbolism, in other words, indicates to a literary movement that originated in France in the last half of the 19th century with Rimbaud, Mallarme, and others (Hugh Holman \& Harmon, 1986). Authors used symbols to express a higher invisible world other than the world of concrete phenomena. As Baudelaire, one of the principal forerunners of the movement said, "human beings live in a forest of symbols, which results from the fact that the materiality and individuality of the physical

Zainalabdeen A.Al Shnain AL-Janabi, Master Degree, The School of Foreign Language and Liteature, Huazhong University of Science and Technology, Wuhan, China.

Aihua Chen, Ph.D., The School of Foreign Language and Liteature, Huazhong University of Science and Technology, Wuhan, China. 
world are transformed into a dark unity and confusion in the world” (Hugh Holman \& Harmon, 1986, p. 495).

Kevin Powers does typically use many symbols in his description of events, characters, to convey his beliefs about the war in a poetic way (Powers, 2012). In literature, symbolism is used to produce an impact, which it accomplishes by attaching additional meaning to an action, object, or name. Symbolism expresses something that is usually concrete and associates or affixes it to something else in order to give it a new and more significant meaning.

On the other hand, symbolism lets a writer express something to his readers in a poetic way instead of saying it outright. These indirect paths let an author create a small difference and complication. Symbols are abundant in this novel. Although the symbols play pivotal roles in understanding the themes, the researches on this subject are insufficient or researchers have not been given due attention. Therefore, the author will try to display symbols in this novel in details.

\section{The Symbolism in Kevin Power's The Yellow Birds}

\section{The Yellow Ribbon}

A yellow-colored ribbon emerges as a symbol of solidarity with soldiers in combat, political hostages, etc. The American folk custom of wearing or displaying a yellow ribbon is to signify solidarity with loved ones or backing to U.S. Army troops, in times of war (Michael, 1999).

Nevertheless, in The Yellow Birds, yellow ribbons come to represent a more annoying fact: most civilians' ignorance of the realities of war. After Bartle and his fellow soldiers leave Germany and land in the U.S., Bartle goes to the airport bar to wait for his flight to Virginia. There, the bartender chats with him about the war and insists on paying for Bartle's beer, pointing to a yellow ribbon as justification for treating this young soldier with deference. Instead of feeling proud and grateful, Bartle becomes annoyed because he does not believe that what he did during the war truly served an elevated, collective ideal. Rather, he knows the only reason why he is now being celebrated — while other soldiers, not as lucky as him, are already dead because he was lucky enough to survive. Bartle thus becomes frustrated because he does not want to accept collective gratitude for an act that was inherently selfish, aimed at protecting his own life. This gap between the public conception of war as an act of self-sacrifice in the name of a greater good and the soldier's understanding of war as a selfish struggle for survival remains unresolved in the novel. However, Bartle's narrative serves to fill some of the public's gaps. It denounces the inadequacy of the glorification of war and suggests that civilians should focus on truly understanding soldiers' experience before emitting an opinion about war's presumed nobility.

I feel like I'm being eaten from the inside out and I can't tell anyone what's going on because everyone is so grateful to me all the time and I'll feel like I'm ungrateful or something. Or like I'll give away that I don't deserve anyone's gratitude and really they should all hate me for what I've done but everyone loves me for it and it's driving me crazy. (Powers, 2012, p. 144)

Bartle feels as though he cannot share his feelings with anyone. His inability to communicate derives from his knowledge that he would shock people by revealing how much pain and guilt war has left him with when everyone keeps on thanking him for what he has done. Bartle does not want to disappoint anyone, nor does he want to burden them with his own suffering. After being so detached from his emotions during the war, Bartle is now experiencing their full force. Their sheer intensity, he discovers, makes him feel separated from everyone 
else since the people around him are simply living their everyday lives without suffering as he does. Bartle's shame thus proves twofold: It is not only related to his actions in the war, but to his inability to share them with anyone, which creates a vicious cycle of guilt. In this situation, in which Bartle does not feel comfortable confiding in anyone, his only hope is to stop feeling guilty for what he has done during a task that he will slowly come to terms with over the next few years.

This section of Bartle's long internal monologue, in which he finally confronts all of the emotions that war has left him with, constitutes the most direct denunciation of the horrors of war. Despite defining shooting and killing as actions that he took part in, Bartle also notes that these are actions that the army and the public condone. Paradoxically, then, society celebrates the very actions that Bartle feels have destroyed his core as a human being “acid seeping down into your soul”. In this way, Bartle denounces society’s moral hypocrisy. Although everyone knows that killing is wrong, war proves to be the great exception to this rule that leads people to celebrate killing instead of condemning it. Even though this moral inconsistency deeply troubles Bartle and condemns him to solitude, by the end of the novel he is forced to accept that he can do nothing to change the moral weight of his actions since these actions have already been committed and belong to the past. All he can do, perhaps, is relating to his own experience, so that it might serve as a much-needed moral and emotional evaluation of war.

Bartle's discontent with this symbol thus proves contradictory. Although one might expect that he, as a veteran soldier, would feel grateful for the signs of civilian support he sees around him, Bartle's resentment derives from his realization that wrong people's realization of the war "symbolized by the yellow ribbon" is overly simplistic and at odds with how the war truly is brutal, destructive, and inelegant. Yellow ribbons thus begin to represent the lack of knowledge that people actually have about an experience of soldiers, as well as Bartle's disability to reintegrate ordinary civilian life, where he feels like an impostor. The yellow ribbon thus acquires a meaning that clashes with its official definition: Instead of highlighting the glory of war, it reveals the gap that exists between public narratives about war which enfold visions of friendship and greatness and the experience of war itself, which is infinitely more complex and unsettling.

\section{Hyacinth Flower}

Hyacinth flower is a bulbous plant of the lily family, with strap-like leaves and a compact spike of bell-shaped fragrant flowers. Native to western Asia, hyacinths are cultivated outdoors and as houseplants (Michael, 1999).

Nevertheless, in The Yellow Birds novel the writer mentions this kind of flower that is usually used to express on life and hope, and he mentioned at the beginning when Malik talked about a woman who was growing them in her garden which was a rare sight: "Mrs. Al-Sharifi used to plant her hyacinth in this field” (Powers, 2012, p. 10). Malik detects his underlying longing for a time before the war, when he could enjoy ordinary inhabitant's life and simple things such as flowers. As the war progressed and all the city of Al Tafar became covered in the dust of war, the hyacinth flowers were only a symbol indicating that the hope is lost.

Bartle also mentioned hyacinth flowers again after Malik died. Bartle said the hyacinth flowers were not like that when we stormed the building, he notes that the place where Malik pointed to the hyacinths is now all burned-up and any trace of ordinary civilian life is gone. This shows that hope was lost when the war came and changed the shape of this hope. He also mentioned when Bartle and Sterling found out Murph's dead body was 
covered in lifeless hyacinth symbolizing the loss of his hope and life. In his daydreams Bartle often thinks about hyacinth flowers back at home and those flowers represent his hope and life.

Furthermore, it is also mentioned by Walter in his article as "scarlet flower". He described it as a recurring image which frames and enhances scenes of death, and he also announced the author of the novel himself uses the image of the hyacinths throughout his work as a framework for brutal death, the very act of speaking in those terms is confronted with the horror of war (Walter, 2017).

\section{Snow}

Traditionally, snow indicates winter and the end of the growing season because of its relation to the end of growth in the natural world. Snow is also linked to death and hardships, and it also symbolizes individuality, changes, and transformation or new beginnings in different cultures. Snow is often used in modern media to predict upcoming wars. Melting snow can be used to symbolize a new beginning, or the end of hardships because snow covers everything and changes a commonplace landscape into something new; it can be linked with transformation. For example, snow is often used to depict a life-changing situation (Juan, 1971).

Snow represents often in the novel, as a harbinger of death, usually in reference to Murph. Bartle mentioned it more than once; it was snowing that night when Captain Anderson comes to arrest Bartle and tells Bartle about Sterling's suicide, and Murph's mother reads the letter Bartle wrote in Murph's name while it's snowing, and it was snowing when Murph's death is reported to his parents, and snow would seem to be a representative not just for death itself, but for the way that death can haunt the living.

Snow can also symbolize individuality, changes, and innocence. Bartel says "I might have thought there was some significance to the fact that there had been snow on the day Murph had come into my life and snow on the day I willed myself into the one that had been taken from him” (Powers, 2012, p. 31). It was snowing when Bartel and Murph met up for the first time. Powers compares snow with Murph's innocence. He describes his innocence before the war distorted this innocence. Bartle's temptation to see snow in a symbolic way reveals his desperation to give meaning to the death of Murph, and Bartle wonders if even random circumstantial details might hold the key to the grand significance of this event.

\section{Birds}

The bird is a symbol of the human soul and it represents goodness, joy, innocence, beauty, wisdom, and intelligence. For other groups like western art, it symbolizes air and touch and throughout the lifetime, the bird flight is the symbol of our soul journeying to the future. Furthermore, birds on flight represent the light of the spirit for hope, and transcendence (Hallberg, 2014).

Birds appear throughout the novel and it gives meaning to the novel's title and sets the tone for the work's description of war and violence. "A yellow bird with a yellow bill was perched upon my windowsill, I lured him in with a piece of bread and then I smashed his fucking head". This military song is included as a quote before The Yellow Birds begins. In the song, the surprising shift from the peaceful setting described in the first stanza and the seemingly gratuitous violence in the song's conclusion suggests that, in a context of war, successful soldiers must learn to perform cruel acts automatically, without reflecting on the moral value of their actions. Here, the birds are collateral damage in a human war, a symbol of the consequences, especially to the innocent, that war can bring. However, if the yellow bird or enemy dies, the murderer becomes a yellow bird of his or her 
own - someone who, at war, is not only constantly exposed to being killed, but who also must give up on their own humanity to become callous killers. By introducing this quote at the beginning of the novel, Kevin Powers exposes the cruel way in which soldiers are meant to feel no compassion for their victims and to follow their violent instincts blindly. As The Yellow Birds shows, becoming so desensitized to violence has severe psychological consequences on soldiers' psyches, as they struggle to figure out how to live with the horrific acts they have witnessed and participated in.

Moreover, when Bartle is back home, after his tour of duty, he writes, "If I heard the caw of ugly crows swing down from the power line that they adorned in black simplicity, the caws might strike in perfect harmony with the memory of the sound of falling mortars” (Powers, 2012, p. 134). The birds, although innocent, here turn "ugly", bringing the war back to the forefront of his mind and becoming sinister. In this section, the birds stand for the way PTSD can infiltrate one's mind and turn something that should be beautiful (life after war) ugly again. Later, Bartle sees an egret flying close to the water and thinks, "there was no way a body could be so close to the edge of a thing and stay there and be in control” (Powers, 2012, p. 143). But, Bartle continues, “The egret didn’t seem to mind what Bartle believed”, and flies off, "full of grace” (Powers, 2012, p. 143). Here, the birds become a symbol not only of Bartle's PTSD, but also of hope. He didn't believe the bird could maintain control on the edge of the water, but it did.

In addition, it also mentioned by Buchanan in his article. He announced that the author includes as an epigraph. Such insider language comes at the expense of other groups of human beings, a mechanism military members use to achieve unity and solidarity through demonizing or belittling linguistic descriptions. Thus, the modern Jodie somewhat accurately reflects the dialectic nature of a soldier's existence; he is an agent of hegemonic violence, but he comforts himself with the idea that all his acts lack agency (Buchanan, 2015).

\section{Seasons}

The symbolism found in seasons has deep roots in literature and they are an integral part of life on Earth. Its effect is not limited to the weather, growth, and agriculture. Seasons also play a role in human mood and consciousness. The change of these seasons is deeply symbolic in and of itself, as it speaks to us of the natural transitions of our planet and of life in general. It also draws a coherent bridge between events that seem simple in our daily lives and the greater world events. Examining the cycles of the seasons lets us to more closely look at the cycles in our lives (Michael, 1999).

In these opening lines of the novel, "The war tried to kill us in the spring” (Powers, 2012, p. 3). The novel begins with the seasons. This notion of the war trying to kill the soldiers is then said also to occur in summer. At first, in this opening chapter, the seasons seem to represent the passage of time, the way Murph and Bartle, obsessed over the number of soldiers killed in the war, remain alive, and not yet counted among the fallen's number. Later, after Bartle and Murph learn from Sterling that this will be the third time they are retaking Al Tafar, Bartle projects into the future: "We'd go back into a city that had fought this battle yearly; a slow, bloody parade in fall to mark the change of season” (Powers, 2012, p. 91). A bit later, Murph says, "Maybe they'll make it an annual thing" (Powers, 2012, p. 91). While the inevitability of the change of seasons can have some comforting aspects, here, the war is compared to the cyclical nature of the seasons which also brings a sense of meaninglessness to their actions. What they are going to be fighting, killing, and dying over will just happen 
again to different people, and nothing will truly change. This meaninglessness becomes one of the things that affect Bartle well after he leaves the army.

Nevertheless, the change in seasons takes on a more hopeful note. As Bartle is flying over U.S. soil once again, he rejoices at the greenery below:

It was spring and some trees bloomed and from this height even the blooms were green and it was so green that I would have jumped from the plane if I could have, to float over that green briefly, to let it be real and whole and as large as I imagined. (Powers, 2012, p. 102)

Even here, despite the giddiness Bartle conveys, it is intermingled with something darker: a plummet to his death, to be "scattered over the earth" (Powers, 2012, p. 103). This is when he remembers the end to the phrase he had started previously, "home. I want to go home” (Powers, 2012, p. 103). In this section, though it ends on a high note, the seasons bring back that darker idea of the cyclical nature of life, foreshadowing that the consequences of the war are not through revealing themselves. The final chapter of the novel, Chapter 11, brings us back to spring when Bartle is being released from prison. This gives the novel a sense of completeness, but also ends on the most hopeful of the seasons, the season of rebirth, as Bartle gets settled in his cabin in the mountains.

\section{The Muezzin's Song}

The muezzin's song is a recurring sensory detail throughout The Yellow Birds. It was introduced in the opening chapter of the novel. In the first mention, shortly after first arriving in Al Tafar, Bartle narrates,

The muezzin's song would soon warble its eerie fabric of minor notes out from the minarets, calling the faithful to prayer. It was a sign and we knew what it meant, that hours had passed, that we had drawn nearer to our purpose, which was vague and foreign. (Powers, 2012, p. 7)

Here, the muezzin's song is a routine element of time's passage. Later, as the battle for Al Tafar intensifies, the muezzin's song begins to appear at the end of chapters.

Bartle concludes Chapter 6 with: "As we continued through the city, people began returning in twos and threes and set about the task of burying the dead. I heard the muezzin's call and the sun went down purple and red, painting the city softly" (Powers, 2012, p. 127). This falls after the majority of the fighting and serves almost like a return to normalcy, though it also serves as a mourning call, as citizens return to bury the dead. The muezzin call also appears at the end of Chapter 8, after Murph sees the female medic killed-the act that ultimately leads to Murph leaving the base and being killed. The final instance of the muezzin comes near the end of the climactic 10th chapter when Sterling and Bartle find Murph's body: "it was clear that he fell from a window where two speakers had been set up to amplify the muezzin's call” (Powers, 2012, p. 205). The symbolism of the origin point of the call to prayer is the point of departure for Murph's body which serves to return us to the idea of the passage of time, and to both beginnings and endings.

\section{Decaying Bodies}

The motif of decay is used to symbolize the impacts of war, to further paint the picture of death. Although the Iraqi enemy represents the most direct physical threat to Bartle's life in Iraq, the true antagonist in the story proves to be the war itself, as it deeply affects Bartle during and after combat. Decaying bodies are mentioned in the novel more than once. Bartle describes the bodies lay bloating in the sun, their decay, an echo of some morbid geometry. Bartle's decision to speak of the war in neutral terms, without mentioning political conflict or hatred 
between him and the enemy, highlights his vision of the war as a force beyond human control. This description also serves to deprive war of any pretention to nobility or glory war. Bartle emphasizes, it is nothing but an evil force that kills human beings, achieving nothing but pain and destruction.

Bartle's perspective sharply criticizes the cruelty of war. It also presents all soldiers and participants in the conflict as victims, falling prey to the pernicious influence of war, trapped in its toxic environment. This description thus insists that no one is individually responsible for the horrors of war. Even though Bartle might have killed people, he cannot be blamed for his role as a soldier. Rather, the true culprit is the harmful, death-obsessed environment that war creates. He sees stray dogs eating the parts of human bodies; the smell of the decay is so distasteful and strong; it overpowers everything else. Bartle no longer notices it as an extraordinary event and has thus automatically become used to considering it yet another aspect of life. "We only pay attention to rare things, and death was not rare” (Powers, 2012, p. 11). The writer tries to embody the impacts of war and its violence and ugliness through this symbolism. He explains this lack of emotion in terms of the context of the war. He describes his reaction both as an automatic process and a necessity. Because death has become so common in this war-torn world, Bartle no longer notices it as an extraordinary event, and has thus automatically become used to considering it yet another aspect of life. In addition, Bartle needs to prevent himself from becoming affected by people's deaths, because feeling too many emotions would keep him from focusing on fighting and survival, the two most important goals in this war. Therefore, becoming indifferent to death is a survival strategy, the self-protective response of the body and the mind to a lethal environment.

However, after the war, Bartle becomes aware of how brutally he behaved and can no longer sustain the indifference that kept him sane during the war. He assigns brutality not only to the explicitly violent acts the soldiers take part in, but also to a more political and cultural aspect of war: the presence of American soldiers on the Iraqi territory. In this sense, war brings more than just death and violence; it also forces a local population to be kicked out of their own homes, see their neighborhoods get destroyed, and generally give up on having self-governing rights over their own territory. Although Bartle never discusses the intricacies of international politics, he remains aware of the human costs of any political action, and uses his own experience to highlight the way in which military or political decisions affect the lives and minds of ordinary human beings.

\section{Murph's Photograph and Casualty Feeder Card}

In his helmet, Murph keeps a photograph of his girlfriend and him, as well as a sufferer feeder card that contains all the information necessary to identify his identity if he dies. Throughout the course of the novel, these two objects represent Murph's gradual detachment from life culminating in his emotional collapse and death, as well as Bartle's try to come to terms with Murph's death culminating in the decision to let go of the past. Although Murph initially keeps the picture and the casualty feeder card in a ziplock bag, revealing how much he cares about his home life and the protection of his own body, he later throws them, leaving them in a laundry bucket, an act that shows how disabused he has become with the war and that highlights his intention to die.

He wanted to decide what he would gather around his body, to refuse that which fell toward him by accident or chance and stayed in orbit like an accretion disk. He wanted to have one memory he'd made of his own volition to balance out the shattered remnants of everything he hadn’t asked for. (Powers, 2012, p. 159) 
After discovering that Murph has abandoned the photograph and casualty feeder card he kept previously in his helmet, Bartle goes to look for him, worried about that these objects might signal that Murph has given up on life entirely. Bartle discovers his companion by the medics' station, watching one of the doctors' daily routine, and realizes that Murph has isolated himself to try to control at least a small part of his time in Iraq: the memories he chooses to make for himself. Unlike Bartle, who has made a mental shield of indifference, Murph has been consumed by the emotions growing inside of him - pain, moral doubt, and confusion which, in times of war, he finds extremely difficult to express. If external events such as battles and sudden deaths have made him feel that he has no control over his own life, he believes that controlling part of what happens in his mind remains his only chance to stay sane. This effort, however, soon fails when Murph is watching the death of a doctor from an unexpected mortar attack. Murph's subsequent emotional devastation proves that the internal peace or comfort he was so desperately seeking cannot exist in a void. Rather, it must hinge on the acceptance that one can never control the external world.

When Bartle finds out these things, he decides to save them. However, after trying to keep Murph's memory alive, Bartle ultimately throws the photograph and sufferer feeder card in the river, discovering that he wants to feel free from the pain and guilt that Murph's death evokes. Through their alternation of protection and abandonment, these objects thus reveal the evolution of Murph and Bartle and their relationship with memory, as each character initially wants to hold onto the past, before deciding for various reasons that they need to let it go. In making Murph and Bartle's difficult relationships with the past and the future more clearly, these concrete things reflect the two characters' potentially fatal struggles to remain sane without giving up on their essential identity as human beings.

\section{Conclusion}

The symbols used in The Yellow Birds reveal the psychological conflict that happens to the soldiers. As the novel shows, becoming so desensitized to violence has severe psychological consequences on soldiers' psyches, as they struggle to figure out how to live with the horrific acts they have witnessed and participated in. Furthermore, symbolism evokes the reader's interest to find out the insight of the author's mind. On the other hand, it reveals how an author is viewing the horror of the war, and what is his point of view towards the psychological conflict to soldiers. In this novel, Powers claims that war is neither glorious nor just, but rather characterized by cruelty and the unpredictability of death. Power's decision to speak of the war in neutral terms, without mentioning political conflict or hatred between him and the enemy, highlights his vision of the war as a force beyond human control. This description also serves to deprive the war of pretension to nobility or glory. He emphasizes war is nothing but an evil force that kills human beings, achieving nothing but pain and destruction.

\section{References}

Buchanan, D. A. (2015). Rotten symbol mongering: Scapegoating in post-9/11 American war literature. Retrieved from https://digitalcommons.du.edu/etd/1014/

Edgar, R., \& Jacobs, H. (1989). Literature: An introduction to reading and writing. Englewood Cliffs: Prentice Hall.

Feidelson Jr, C. (1953). Symbolism and American literature. Chicago and London: Univ. of Chicago Press.

Hugh Holman, C., \& Harmon, W. (1986). A handbook to literature. New York: Macmillan Publishing Company.

Hallberg, O. (2014). Animal symbols meaning. Bird Symbol. Retrieved from https://www.animal-symbols.com/bird-symbol.html Juan, E. C. (1971). A dictionary of symbols (J. Sage, Trans.). New York: Philosophical Library. 
May, R. (1960). Symbolism in religion and literature. NY: G. Braziller.

Michael, F. (1999). A dictionary of library sysbols. Cambridge: Cambridge University Press.

Perrine, L., \& Arp, T. R. (1974). Literature: Structure, sound, and sense. San Diego, California: Harcourt Brace Jovanovich.

Powers, K. (2012). The yellow birds: A novel. NY: Little, Brown.

Walter, A. (2017). "What it felt like": Memory and the sensations of war in Vergil's Aeneid and Kevin Powers' The yellow birds. Journal for Transcultural Presences and Diachronic Identities From Antiquity to Date. Retrieved from http://www.thersites.uni-mainz.de/index.php/thr/article/view/37/48 